\title{
Trust levels in SME Export Networks in Ghana
}

\begin{abstract}
Albert Martins
Department of Marketing, University of Professional Studies, Accra

Abstract

The purpose of this paper is to explore the levels of trust within small and medium-scale enterprise export networks, using Ghana's Export Associations (EAs) as a case study. Exploratory and case study designs were employed for the study. Besides, the study adopted the mixed-methods approach, involving the collection of qualitative data from 19 EAs via semi-structured interviews, and analysed thematically using Nvivo 12. Quantitative data was also collected from 259 SME exporters and statistically analysis (i.e. mean, standard deviation and correlation) was done using SPSS. The results indicated low trust between SME exporters and EA leaders (vertical trust). EA leaders had low trust for SME exporters regarding financial commitment; meeting attendance and sharing trade information. SME exporters had low trust for EA leadership in communicating information, adhering to promises, members' interest and acting with equity. There was low trust among SME exporters (horizontal trust). Additionally, there was much more 'horizontal trust' than 'vertical trust' within EAs. The study provides a framework for analysing the effectiveness of SME export networks. Academics and policymakers will find the results useful when analysing governance and relationships within export networks. This paper is significant in separately measuring trust within networks from vertical and horizontal perspectives.
\end{abstract}

Keywords - Trust levels, Trust Theory, SME, Export Networks, and Export Associations

DOI: $10.7176 / \mathrm{JMCR} / 67-08$

Publication date: April $30^{\text {th }} 2020$

\section{Introduction}

In the contemporary globalized trade regime, cooperation is a required response to intensified global competition, and joint action is essential for responding successfully to major challenges in business involving developing countries (Rutashobya \& Jaensson, 2004). Cooperation (especially horizontal cooperation) among small and medium scale enterprises (SMEs) contributes to collective efficiency, resulting in cooperation advantages usually derived either from economies of scale (in purchases, sales, investment in infrastructure, dealing with buyers, etc); the benefits of dissemination of information (on technology, on markets, etc) or the benefits of division of labour, which can best be reaped when transactions costs are low (Madhok 1997; Berry 2002). As SMEs are considered the catalyst for export growth for developing countries, there is a compelling case for networking amongst sub-Saharan African small firms (Ibeh, 2003) because they may have to rely on networks and relationships to overcome their size disadvantages as they internationalize (Madhok, 1997; Rutashobya \& Jaensson, 2004). Thus partnering through export networks is an alternative way for many resource-constrained SMEs to end their isolation in the current highly competitive world trade and to become competitive in foreign markets (Ruzzier, Hisrich \& Antoncic 2006). It follows that export networks are essential to meeting new customers, winning new business, building existing partnerships and delivering on contracts. Coviello and Munro (1997) noted that networks involve providing a competitive advantage to small firms, because of possibility of resource sharing and learning among network members that could enable them minimize their size disadvantages. Network links between interrelated firms are increasingly recognized as a key organizational growth resource, while networking activity facilitates knowledge transfer and learning which define the shape and trajectory of a firm's growth (Macpherson \& Holt 2007). Networks are effective solution to address the constraints connected with SMEs (Cannatelli \& Antoldi, 2012; Antoldi, Cerrato \& Larocca, 2017).

Export networking arrangements, whether in the form of export consortia, client-fellowship, entrepreneurial networks or international ethnic ties have been shown to mitigate, for the smaller firms, some of the size and experience-related difficulties associated with export venturing (Wignaraja 2003). Export networks ensure better export performance and therefore have a significant positive influence on SMEs export performance (Babakus, Yavas \& Haahti 2006). Export networks help firms to expose themselves to new opportunities and obtain knowledge (Chetty \& Holm, 2000) and increase experiential knowledge (Blomstermo et al., 2004). Thus, acting in a network context, SME exporters can penetrate and increase their share of foreign markets at reduced cost and risks, improve their profitability, achieve productivity gains, and accumulate knowledge through various types of joint action and overcome export trade impediments and further marginalization (UNIDO, 2007). Wignaraja (2003) however observes that with some notable exceptions, many SME export networks in developing countries are very small and informally organized, and lack the human capacity, financial resources and know-how to provide a wider range of support services to SMEs. It is important 
to note that export networks thrive in an environment of trust or levels of trust (Li, 2007), as the existence of competency trust, contractual trust and goodwill trust is required for successful export networks (Sako, 1992).

Considering the significance of export networks to SMEs' export performance in developing countries say Ghana, it is important to explore the activities of Exporters Associations (EAs) which is mostly involved with Non-Traditional Export (NTE). Ghana's NTE sector is central to her export growth and economic development. Being dominated by SME exporters, the sector has historically not performed as expected, in spite of huge government and private sector interventions. Ghana Export Promotion Council (2010) noted that since 2005 the NTE sector had not been able to achieve its annual targets. So, in a bid to increase export revenue, the government of Ghana had set a five-year target (2010-2015) to achieve US\$5 billion in NTE revenue by the end of 2015 (Ministry of Trade and Industry, 2011). However, recent report on the performance of the NTE sector indicates inconsistent growth since 2013; while there was a steady growth from 2013 (US\$2.44m) to 2015 (US\$2.52m), it declined in 2016 (US\$2.46) and rose up again in 2017 (US\$2.56) (Ghana Export Promotion Authority, 2017). Among other interventions to support the NTE sector, EAs have been established to boost SME exporters' performance. EAs are voluntary product-based horizontal export networks (Ghauri, Lutz \& Tesfom, 2003) formed by the Ghana Export Promotion Authority (GEPA) with a mandate to support SME Exporters in the NTE sector attain international competitiveness. However, evidence from GEPA suggests that EAs are ineffective and beset with problems including members' low commitment and poor participation. Furthermore, lack of trust within EAs has often been cited as a fundamental factor inhibiting their effectiveness and progress. Trust between partners is often cited as a critical element of network exchange that in turn enhances the quality of the resource flows affecting the depth and richness of exchange relations, particularly with respect to the exchange of information (Lorenzoni \& Lipparini, 1999; Hite, 2000). Trust is said to be an essential variable that must not be overlooked in building relationships (Welter 2012; Fink \& Kessler 2010), and it is noted to have a positive effect in lending relationships (Moro, Fink \& Kautonen, 2014) as well as significantly contributes to build cooperation in export networks (Roloff 2008; Massaro, Moro, Aschauer \& Fink, 2017). Therefore, "trust is the foundation of any business relationship, particularly in the development of long term co-operations" (Ismail, 2011).

The author argues that as trust increases satisfaction with interaction (Geyskens, Steenkamp \& Kumar, 1998), binds relationships (Ring, 1996), builds commitment (Warrington, Abgrab \& Caldwell, 2000), and supports arrangements that imply intensive behavioural uncertainty owing to inter-firm cooperative network relations (Doz 1996; Van de Ven \& Ring 2006; Massaro et al., 2017), it is worth ascertaining trust levels within EAs for managerial and policy-making interventions in improving EAs. The author further argues that as trustinduced well-integrated export groups were targeted for support in East Asia resulting in improved export performance by small East Asian firms (Sharma \& Morrissey 2006), similarly EAs operating in the context of high trust and close cooperation could be targeted for support by stakeholders to enable them function effectively and though there is extensive literature on Ghana's NTE sector (Kastener, 2005; Kyereboah-Coleman \& Biekpe, 2006; Buatsi, 2002; Hinson, 2005; Owusu-Frimpong \& Mmieh, 2007) so far, there has not been any research examining the levels of trust within EAs in Ghana. Lyon (2000) researched on trust, networks and norms in Ghana, but only focused on the means of creating trust. To date, the levels of trust within Export Associations in Ghana have not been explored. Thus the present study sought to fill this research gap thereby revealing the various levels of trust and their importance in the SME export networks within EAs, and how the EA leaders can cultivate trust among themselves as well as between SME exporters to facilitate export cooperation.

\section{Literature Review}

\subsection{Concept of Trust and Trust levels}

Trust is an integral part of what is called social capital and reflects features of social capital that are possible to objectively measure to a lesser extent (Lyon, 2000). Parkhe (1998) sheds light on the concept of trust and argues that, in the context of alliances, trust is seen to have important psychological, sociological and economic properties simultaneously. The increased propensity for cooperation also enhances trust in a process of mutual dependence, a process which results in an accumulation of social capital (Putnam, 1993). Thus, trust is a relational phenomenon which enhances cooperation. An organization's ability to develop trusting relationships is an increasing important source of competitive advantage (Barney \& Hansen, 1994) requiring that organizations and the members they are comprised need to be both trustworthy and trusting (Watson, 2005). The study of trust is multi-dimensional and multi-faceted (Misztal, 1996). Similarly, Velez (2000) contends that the understanding of the concept of trust requires multi-level perspective and flexibility in that trust is considered as an intricate phenomenon that can manifests itself at various levels. Trust thus can manifest at the levels of individual, group and organizations, and/or between inter-firms (Bhati, 2015).

Earlier studies on trust have explored various levels of trust (e.g. Individual, group, institutional) trust both within and between organisations and various causal roles of trust (e.g. trust as cause and outcomes and 
moderator) (Rousseau et al., 1998; Bhati, 2015). Li (2007) states that there is no consensus on specific dimensions of trust and concludes that the trust literature appears to converge towards two necessary conditions (uncertainty, vulnerability) and two functions (expectations of being trustworthy, willingness to trust) in most trust definitions. Svensson (2005) suggests that trust means that somebody is willing to take a risk or expose himself in relation to somebody else. Sako (1992) identified the components of trust as competency trust, contractual trust and goodwill trust. Trust not only varies in the form that it may take but also exists at a variety of levels such as team level (among team members), leadership level (between the team members and the leader), the organizational level (between the employees and the organization), and inter-organizational level (between organizations) (Burke et al., 2007). Therefore, Putnam (1993) posits that trust can be divided into 'vertical trust' in the institutions of society (institutional trust), and 'horizontal trust' or generalized trust in other people. Watson (2005) identified many measurements of trust and argues that there may be one trust that is applied differently inter-organizationally and interpersonally, and therefore require separate measurements. Watson continues to argue that from an empirical standpoint it does not appear that a widely accepted and used measurement instrument for trust has emerged, rather, it seems to be the case that different researchers use different measurement instruments to meet their specific purpose, so many measurement instruments are used (Watson 2005).

\subsection{Trust Theory and its Antecedents}

Bhati (2015) noted the use of trust theory in business relationships has emerged as an expectation that another's action will be advantageous rather than disadvantageous (Gambetta, 1988); thus trust is considered as "an important factor in all market transactions and market freedoms could be inconceivable without a social order rooted in community norms including trust" (Etzioni, 1988; Granovetter, 1985; cited in Bhati, 2015). The emergence of trust is traceable to business crises (especial financial crises) emanating from lack of transparency, integrity and doubtful honesty of some people in business (Uslaner, 2010). Available literature on trust summarised the definitions of trust into 'confident expectations' and 'willingness to be vulnerable' (Velez, 2000; Bhati, 2015). Trust is a serious issue for multi-agent systems which generally consist of a collection of agents that interact with one another in dynamic contexts (Ma \& Orgun, 2006). Thus, trust theory is a set of rules (axioms) that describes trust of agents in a given system (Ma \& Orgun, 2006).

The study of trust is based on a number of approaches namely: psychological approaches to trust which focus on the personality traits of an individual (Rotter, 1980), sociological approaches to trust - which interpret trust as individual characteristics perceived by others as trustworthy (Dasgupta, 1990) or observed behaviour of individuals in situations that exposes them to the probability of risk (Worchel, 1979). However, Lewis and Weigert (1985) liken trust to the relations among people or firms rather than psychological state of individuals. In a more recent study, Dibben (2000) classifies trust into three stratums: dispositional trust (the psychological disposition or personality trait of an individual to be trusting or not trusting), learnt trust (an individual's general expectancy to trust or not to trust another individual as a result of experience), and situational trust (which is dependent on the situational cues that modify the expression of generalised tendencies). He further suggests that dispositional trust is contingent upon individual's disposition or the character trait but learnt trust grows out of individual's experience in relating with another individual, and the situational trust rely on the interaction with individuals in particular circumstances (Dibben, 2000; Bhati, 2015).

\subsection{Trust and Export Networks}

Previous research has cited trust between partners as a critical element of network exchanges which, when developed, enhances resource flow (Lorenzoni \& Lipparini, 1999). When parties trust each other, they are more willing to engage in cooperative activity through which further trust may be generated (Fukuyama, 1995). The exchange of business information requires mutual trust in alliances, partnerships or networks and in channels when the exchange goes beyond direct relationships towards connected relationships (Hakansson \& Snehota, 1995). The positive effects of trust on performance outcomes include achievement of financial and non-financial goals (Brouthers \& Bamossy, 2006). Sako (1998) asserts that trust enables a network of firms to adapt to continuous improvement and innovation or 'learning'. In support, Lau \& Rowlinson (2010) suggest that trust has a direct effect on work group process and performance, citing Dirk's, (1999) findings that better coordination and efficiency, hence better performance, are found in a high-trust groups. The importance of trust can be explained by the fact that it is seen as a phenomenon which contributes to the strength of inter-personal relationships, intra-organizational relationships and inter-organizational relationships in business networks (Gronroos, 2000; Hakansson \& Snehota, 1995; Morgan \& Hunt, 1994).

Tyler and Stanley (2007) demonstrate the functionality of trust and its relevance in the network context citing various researchers as follows: Trust is a source of competitive advantage (Barney \& Hansen, 1994) and increases satisfaction with interaction (Geyskens et al., 1996); Trust reduces transaction costs (Andaleeb, 1992), limits uncertainty and opportunism (Achrol, 1997; Busch \& Hantusch, 2000) and creates flexibility (Nooteboom, 
1996); Trust binds relationships (Ring, 1996) and builds commitment (Warrington, Abgrab \& Coldwell, 2000); Trust improves communication (Anderson \& Narus, 1989), enables risk taking and facilitates co-operation and mutual adaptation (Hewett \& Bearden, 2001). Trust in leaders is particularly important for effective functioning teams and organizations where tasks are complex and unstructured, and require high levels of interdependence, cooperation, and information sharing (Creed \& Miles, 1996). However, Ma and Orgun (2006) argue that in spite of the significance of trust, there are some fundamental problems with it including what trust is and what kind of trust relations we may need in any system as different forms of trust exist to address different types of problems and mitigate risks in certain conditions.

In summing up, the extant literature shows that both trust and export networks have attracted the attention of many researchers (Andaleeb, 1992; Creed \& Miles, 1996; Achrol, 1997; Busch \& Hantusch, 2000; Hewett \& Bearden, 2001; Gronroos, 2000; Brouthers \& Bamossy, 2006; Ma \& Orgun, 2006; Kastener, 2005; Kyereboah-Coleman \& Biekpe, 2006; Buatsi, 2002; Hinson, 2005; Owusu-Frimpong \& Mmieh, 2007; Lau \& Rowlinson, 2010; Welter 2012; Bhati, 2015; Massaro et al., 2017). However, there is existing research gap as far as trust levels in SME export networks in Ghana is concern. Therefore, the present study aimed to explore trust levels in SME export networks with special reference to EAs in Ghana. Thus the research question was - What are the levels of trust within Export Associations in Ghana? To assist answer the research question, the following specific objectives were set: (i) To identify the trust dimensions relevant to Export Associations in Ghana; (ii) To measure the levels of trust existing in Export Associations in Ghana and, (iii) To compare horizontal and vertical trust relationships existing within Export Associations in Ghana.

\section{Methodology}

Mixed methods was adopted for this study, as it provides more perspectives on the phenomena being investigated and results in more robust and reliable findings that lend themselves to more valid and reliable generalizations (Easterby-Smith, Thorpe \& Lowe, 2004). Mixed-methods research ensures that the overall strength of a study is greater than either qualitative or quantitative research (Creswell \& Clark, 2007). Tashakkori and Teddlie (2003) however argue that mixed-methods may lack the required depth, as resources would have to be thinly apportioned to two methodologies instead of one, and the researcher may end up not doing both well. Laws (2003) in support, cautions that accounts collected from different perspectives may not match tidily and there may be mismatches or even conflict between them, hence the need to critically examine the meaning of any mismatches to make sense of them. Creswell (2007) further notes that the mixed-method approach poses some challenges for the inquirer, including the need for extensive data collection, the timeintensive nature of analysing both text and numeric data, and the requirement for the researcher to be familiar with both quantitative and qualitative forms of research. These challenges were considered and factored into the research design.

For the qualitative dimension of the study, the author employed a case design which is most recommendable under qualitative research (Yin, 2013). This design enabled the author to explore and have indepth understanding of the trust levels in SME export networks of the EAs. Appropriately, semi-structured interviews were held with leaders of 19 EAs by employing purposive sampling drawn from a sample frame obtained from GEPA. The semi-structured interview technique adopted exposed the study to interviewer bias. To avoid this tendency, the author ensured that questions were carefully asked and non-verbal behaviours were not suggestive. Thematic analysis supported by Nvivo12 was used to analyse qualitative data. To deal with the bias of interpretation, the author was vigilant, critical of data interpretation and highly alert to the tendency of overweighting any facts because of personal beliefs (Saunders, Lewis \& Thornhill, 2009).

Survey design was also employed under the quantitative approach. Thus a paper-based questionnaire that provides a high degree of confidence in the process (Hair et al., 2006) was used to collect the quantitative data. The questionnaire was based on five point Likert rating scale anchored on " 5 " for very high to " 1 " for very low, with six items. Various conceptualizations of trust based on a review of the literature and insights from GEPA and the Federation of Associations of Ghanaian Exporters (FAGE) were measured. These included risktaking (Svensson, 2005); willingness to do more than is formally expected (Sako, 1992); placing other's interest ahead of own (Sako, 1992); adherence to written or verbal promises (Nicholson et al., 2001); acting with equity (Ring \& Van de Ven, 1992); information exchange willingness (Johnsen, 1999); and capability and expertise to perform (Sako, 1992). Based on the stratified sampling technique employed, questionnaires were administered face-to-face to ensure high participation (Cavulsgi \& Noar 1987) to a sample size of 270 SME Exporters. However, out of the 270 respondents contacted, 259 validly co-operated, resulting in a 96\% response rate which is acceptable for the analysis (Tabachnick, Fidell \& Osterlind, 2007). Means and standard deviations were calculated using Statistical Package for the Social Sciences (SPSS version 21) to enable comparison of trust types and trust levels, whilst Cronbach's alpha coefficient provided an indication of internal consistency. Trust was measured from two perspectives of (i) Vertical trust or SME exporters trust for EA leaders and EA leaders trust for SME exporters and (ii) Horizontal trust or trust among SME exporters (Putnam, 1993). All the ethical 
requirements of the research were met. Practitioner relevance (Thomas \& Tymon 1982) was ensured to provide the study with descriptive relevance; goal relevance; operational validity; non-obviousness and timeliness.

\section{Results}

The qualitative method was employed to assess one dimension of vertical trust (EA leaders trust for SME exporters). During semi-structured interviews, 19 EA leaders were asked to assess the importance of trust in the network contest. All respondents clearly understood the role and high importance of trust as an indispensible binding factor. EA leaders were further required to describe the extent of trust they had for SME exporters in the network context, based on three trust dimensions suggested by GEPA - information sharing by members with the Association; members' financial commitment; and members' attendance to Association meetings and programmes. Majority of EAs (13 out of 19) responded they had low trust for their members in terms of financial commitment. An overwhelming majority of EAs (16 out of 19) had very low trust for members' attendance to Association meetings and programmes. Only six EAs trusted their members to a large extent to share trade information they sourced independently, whilst majority EAs trusted their members only to a little extent, as expressed by an EA president in the agricultural sector.

"We know they do not trust us and we do not trust them too. They are so unreliable when it comes to monetary issues. They are unwilling to pay their dues and make any financial contribution. Majority of our members cannot be trusted to attend meetings. For a lot of them we only see them once a while. We see them at GEPA programmes, not at our meetings. You can only trust a few to share information with us. They keep things to themselves".

Asked to explain the low trust they had for their members in terms of the areas described above, majority EAs cited member's unwillingness and actual non-payment of monthly dues; members reluctance to attend meetings and programmes evidenced by high absenteeism and member's unwillingness to share trade information with EA leaders but rather among themselves. The vice president of an EA in the handicraft sector affirmed majority EAs position thus:

"They accuse us of not being transparent, yet when you call meetings, they do not respond. They give all sorts of excuses. You cannot trust to get them when you need them. Concerning information sharing with we leaders, well, I think it is mostly new exporters who do so. The old members do not. It is a big struggle with members talking about monthly dues. You cannot trust them there. Most of them have months of outstanding dues."

Asked to suggest steps that could be taken to increase current low trust they had for their members, EAs suggested that members should show more commitment in the respective areas described. Nearly a half of EAs admitted that EA leaders equally have the responsibility of ensuring vibrant and progressive Associations to gain the interest and patronage of SME exporters.

To measure the second perspective of vertical trust (SME exporters trust for EA leaders), SME exporters were required to rate six selected dimensions of trust. Index values close to five showed relatively higher perceived levels of trust, while values close to one suggested low levels of trust. A mean score of three therefore showed an average level of SME exporters' trust for EA leaders. After this computation, an index of the overall level of trust perceived by the respondents was estimated by taking the average scores over all the trust dimensions. Table 1 depicts the trust dimensions and their corresponding scores.

\section{Table 1:}

Ranked Dimensions of SME Exporters Trust for EA Leaders and Sample Statistics

\begin{tabular}{llllll}
\hline Trust Components & Mean & SD & Min & Max & Range \\
\hline Performing as expected & $3.07^{* *}$ & 0.68 & 2 & 4 & 2 \\
Communicating information & $2.73^{* *}$ & 0.93 & 1 & 4 & 3 \\
Willingness to take risk for members & $2.67^{* *}$ & 1.01 & 1 & 4 & 3 \\
Adhering to promises & $2.54^{* *}$ & 0.72 & 1 & 4 & 3 \\
Placing Members' interest first & 2.33 & 0.59 & 1 & 3 & 2 \\
Acting with equity & $1.86^{* *}$ & 0.72 & 1 & 3 & 2 \\
\hline
\end{tabular}

SD denotes standard deviation; Min and Max denote minimum and maximum respectively

** denotes significance at the 5 percent level down the column. 
From Table 1, SME exporters highest trust dimension is 'performing as expected' (mean=3.07, $S D=$ 0.68 ) which is statistically significant. As membership of EAs is not mandatory, this result indicates that SME exporters join EAs because they trust EAs to 'perform' including assisting them leverage needed resources for their export businesses. On the contrary, 'acting with equity' (mean=1.86, $S D=0.72$ ) was the least trust dimension, an indication of exporters' perception of EAs as discriminatory in resource or export contract allocation to members. The minimum of one and maximum of three for the dimension 'acting with equity' suggests that none of the exporters chose 'very high trust' or 'high trust', further illustrating the extent to which SME exporters perceive EAs as discriminatory. It is important to observe from table one that all except one trust component (placing member's interest first) are statistically significant. Table 2 presents an inter-item correlation matrix which illustrates how SME exporters' perception about each trust component could affect other trust components.

Table 2: Inter-Item Correlation Matrix for Vertical Trust

\begin{tabular}{|c|c|c|c|c|c|c|}
\hline Components & 1 & 2 & 3 & 4 & 5 & 6 \\
\hline 1.Willingness to take risk for members & 1.00 & & & & & \\
\hline 2. Acting with equity & 0.67 & 1.00 & & & & \\
\hline 3. Placing members' interest first & 0.29 & 0.42 & 1.00 & & & \\
\hline 4. Performing as expected & -0.07 & 0.01 & 0.44 & 1.00 & & \\
\hline 5. Adhering to promises & 0.14 & -0.01 & 0.05 & 0.21 & 1.00 & \\
\hline 6. Communicating information & 0.18 & -0.16 & -0.07 & -0.06 & 0.42 & 1.00 \\
\hline
\end{tabular}

Reading vertically from table 2 , 'willingness to take risk for members' is positively correlated with components such as 'acting with equity', 'placing members' interest first', 'adhering to promises', 'communicating information' but negatively correlated with 'performing as expected'. This implies that SME exporters who assigned high levels of trust to 'willingness to take risk for members' would also likely assign high levels of trust to those components it positively correlation with. However, the more exporters develop trust for leaders' 'willingness to take risk for members', the less the likelihood of trusting leaders to 'perform as expected'. Table three below, shows results of the measurement of horizontal trust (trust among SME exporters) within EAs.

Table 3:

Ranked Components of Trust among SME Exporters and Their Sample Statistics

\begin{tabular}{|c|c|c|c|c|c|}
\hline Trust Components & Mean & SD & Min & Max & Range \\
\hline Adhering to promises & $3.81 * *$ & 0.98 & 2 & 5 & 3 \\
\hline Acting with equity & $3.41 * *$ & 0.71 & 2 & 4 & 2 \\
\hline Performing as expected & 3.00 & 0.64 & 2 & 4 & 2 \\
\hline Willingness to take risk for others & $2.46^{* *}$ & 0.96 & 1 & 4 & 3 \\
\hline Placing Members' interest first & $2.07 * *$ & 0.77 & 1 & 3 & 2 \\
\hline Communicating information & $1.86 * *$ & 0.72 & 1 & 3 & 2 \\
\hline
\end{tabular}

$S D$ denotes standard deviation; Min and Max denote minimum and maximum respectively

** denotes significance at the 5 percent level down the column.

In table 3, 'adhering to promises' is the highest dimension of trust SME exporters have for each other (mean $=3.81, S D=0.98$ ) which is statistically significant. This result may be explained by the 'contract-sharing' culture among SME exporters who team up to meet large export contracts due to low individual outputs, a view reinforced by the observation that of the trust dimensions, only 'adhering to promises' scored a 'very high' on a mean score of five. On the contrary, 'communicating information' (mean=1.86, $S D=0.72$ ) is the least trust component SME exporters have for each other. Low trust for 'communicating information' reflects SME exporters 'individualism' and selfishness in sharing trade information. Table 4 illustrates the overall level of vertical and horizontal trust among EAs. Table 4 also presents the internal consistency of the measured components, that is, the Cronbach's alpha coefficient. 
Table 4: Overall Trust Mean and Indicator of Internal Consistency

\begin{tabular}{|c|c|c|c|c|c|c|c|}
\hline Variable & $\begin{array}{l}\text { Items } \\
\text { No. }\end{array}$ & $\begin{array}{l}\text { Mean } \\
\text { Score }\end{array}$ & Min & Max & Range & $S D$ & $\begin{array}{l}\text { Chronbach } \\
\text { Alpha }\end{array}$ \\
\hline $\begin{array}{l}\text { Vertical Trust } \\
\text { (Trust for EA Leaders ) }\end{array}$ & 6 & 2.53 & 1.86 & 3.07 & 1.21 & 0.167 & 0.54 \\
\hline $\begin{array}{l}\text { Horizontal Trust } \\
\text { (Trust among SME exporters) }\end{array}$ & 6 & 2.77 & 1.86 & 3.81 & 2.04 & 0.588 & 0.51 \\
\hline
\end{tabular}

The overall low vertical trust reported in table 4 (mean scores of 2.53 and $2.77<3$ ) is supported by an observation in table 1, where none of the exporters rated any of the trust components as 'very high' (5) on the maximum statistics. For vertical trust, the Cronbach's alpha coefficient which measures the level of internal consistency among the rated components was 0.54. Granted that the Cronbach's alpha reliability coefficient normally ranges between zero and one, with a 'good' alpha level anything above 0.8 (Scott and Mazhindu, 2005), the reported alpha of 0.54 in table four may be low. However, considering that the number of 'items' on table 4 is six and not above ten, the reported Cronbach's alpha of 0.54 is acceptable (Tabachnick et al., 2007). On the strength of this argument, it could be said that the reliability among the answers is acceptable. Table 4 further indicates that 'Horizontal' trust is low, based on the overall mean score of 2.77 being less than three. The Cronbach's alpha coefficient of 0.51 suggests poor but acceptable reliability among the answers. Low trust among SME exporters confirms the view of EA leaders, GEPA and FAGE that SME exporters are individualistic, a perception supported by an observation in table three where, 'placing members' interest first' recorded a low mean of 2.07 among SME exporters. Table 4 furthermore reveals that there is more horizontal trust than vertical trust within EAs (Horizontal trust mean $=2.77>$ Vertical trust mean $=2.53$ ).

\section{Discussion}

From table 1, SME exporters demonstrated the highest trust for leadership in terms of 'performing as expected' (mean=3.07, $S D=0.68$ ). This indicates that SME exporters (mostly the young or inexperienced) join EAs because they trust EAs can 'perform as expected' by assisting them leverage needed resources for their export businesses. On the contrary, 'acting with equity' (mean $=1.87, S D=0.72$ ) was the least type of trust exporters had for EA leaders, implying that SME exporters mostly do not trust their leaders to be equitable, possibly with respect to exporters' perception of EAs as discriminatory in resource or contract allocation to members. This finding is consistent with Van de Ven's (1999) view that trust persists on the basis that the other party will fulfil its commitments to generate equitable relationship.

Table 4 suggests that there is more horizontal trust than vertical trust within EAs, an imbalance in trust that does not facilitate co-operation and mutual adaptation within the EAs as advocated for by Hewett and Bearden (2001). The reported low vertical trust in table 1 is affirmed by qualitative findings which cited an EA's president's comment: "We know they do not trust us and we do not trust them too". The existing low commitment and poor relationships among EAs demonstrated by the above statement confirms the position of Warrington, Abgrab and Coldwell (2000) that trust builds commitment and binds relationships.

The reported low interaction levels between SME exporters and Association leaders confirms Williamson's (1995) view that repeated personal interaction discourages attempts to behave in an opportunistic manner and increases the level of trust. The low trust for SME exporters to share information reported in the qualitative findings supports the results in table 3, where 'communicating information' among SME exporters produced the least mean of 1.86. The research revealed that though SME exporters did not patronize EA meetings and programmes nor showed financial commitment, they trusted EAs to 'perform as expected' shown by the highest mean score of 3.07 in table one. This suggests that SME exporters still have confidence in EAs to deliver trade support, and are likely to show commitment to them once they address the concerns of SME exporters. Evidence from table 1 suggesting 'acting with equity' as the lowest trust dimension (mean=1.86), and 'adhering to promises' as a low trust dimension with a mean of 2.54 supports the position of Ring and Van de Ven (1992) that trust persists on the basis that the other party will fulfil its commitments to generate equitable relationship.

The author argues that as SME exporters have willingly joined EAs (rather than having been compelled by legislation) they would have done so on the basis of trust; trust that the EAs would provide support and deliver specific benefits to them being small exporters. If they are not currently actively involved in EAs as complained about by EA leaders, then it is quite safe to conclude SME exporters have lost competency trust, contractual trust and goodwill trust (Sako, 1992). The existing lack of trust in the EAs and its accompanying costs to members as revealed in the findings is consistent with the assertion of UNIDO (2004), that hidden agendas of the members and competition instead of cooperation can also incur risks and costs. Networking 
theory argues that trust is a viable governance structure in a dynamic network environment (Hakansson \& Johanson, 1993).

The weak relational, operational and network strength of EAs evidenced through the research confirms the view of Morgan and Hunt (1994) as well as Gronroos (2000) that trust is a phenomenon which contributes to the strength of inter-personal relationships, intra-organizational relationships and inter-organizational relationships in business networks. It could be further argued from the foregoing that EAs are bereft of social capital, given the lack of cooperation and trust amongst them, a situation confirming Putnam's (1993) view that the increased propensity for cooperation enhances trust in a process of mutual dependence resulting in an accumulation of social capital.

The author argues that the low level of both vertical and horizontal trust within EAs is worrying, considering the strategic importance of EAs in Ghana's export development strategy, and calls on EA leaders to cultivate a trust-building culture with respect to not only SME exporters, but also to EPAs and other industry stakeholders. This call is supported by Barney and Hansen (1994) as well as Watson (2005) who state that an organization's ability to develop trusting relationships is an increasing important source of competitive advantage, requiring that organizations and their members need to be both trustworthy and trusting. On the other hand, SME exporters should build trust among themselves to take EAs forward; a suggestion consistent with Fukuyama's (1995) view that when parties trust each other, they are more willing to engage in cooperative activity.

\section{Practical implications}

The present study has underscored the importance of trust in export business relationships and the need to deconstruct trust in any analysis of its role in business networks. Departing from a holistic analysis of 'trust' and monitoring trust's multi-dimensional components, export network managers could be more effective in relating to and managing their members. Considering the positive link between trust and productivity, network managers should identify, monitor and consistently improve trust components and trust building factors. Export network managers should cultivate the attitude of trust through teamwork, transparency, good communication and adherence to operational policies and procedures. Trust building seminars and training workshops could also be organized not only by EAs, but by Export Promotion Agencies, the government and industry stakeholders. EAs would have to improve their governance structures and management approaches in order to earn the trust and commitment of members, as well as gain the confidence of Export Promotion Agencies and the Government. Consistent with the current global wave advocating for a partnership approach to international business, SME exporters should be encouraged to develop a partnership mentality rather than individualism.

\section{Conclusion and suggestions for future research}

The present study explored the trust levels in SMEs export networks with special reference to EAs in Ghana. The findings affirmed the importance of trust in business relationships yet there was low interaction levels between SME exporters and EA leaders, therefore EA leaders need to build trust between themselves and SME exporters, and equally encourage trust among SME exporters. As trust is a sine-qua-non in any successful network relationship, it is imperative that inter-firm trust be developed and sustained, and it behoves on EA leaders to endeavour to build trust between themselves and SME exporters through fairness, transparency and commitment to the goals of the EAs and the expectations of SME exporters. Without trust, an atmosphere of suspicion thrives, promoting disharmony and disunity which stifle progress. If EAs are to support SMEs to become more competitive, trust must be cultivated within EAs.

'Trust' was deconstructed into vertical trust and horizontal trust, a technique found to be useful, as it revealed more 'horizontal trust' than 'vertical trust' within EAs; thus confirming the significance of horizontal trust in SME export networks. There is the need for export network managers to deconstruct trust into component parts as described in the trust literature, and effectively manage all components. This is likely to foster productivity, considering the positive link between trust and productivity. The findings further highlighted the power of trust in the socio-economic agenda of developing countries, by revealing that trust greatly influences not only the performance of SME exporters in Ghana, but by extension, determines the performance of Ghana's export sector and ultimately Ghana's GDP. This research thus confirms the importance and power of trust.

Although the findings make important contributions to the SME and international business literature, the cross-sectional approach adopted (rather than longitudinal) does not reveal how trust levels have changed over time in the current highly dynamic export business. Future research should, therefore, consider a longitudinal approach to studying trust in EAs in order to establish 'trust changes' over time in the highly dynamic export business. Future research could adopt a different combination of mixed-methods, for example by combining the survey method with focus groups or projective techniques to yield deeper insights, or perhaps by focusing on a quantitative study to measure dimensions of trust in more detail. 
References

Antoldi, F., Cerrato, D. \& Larocca, A. A. (2017). Trust and control in strategic networks: An empirical analysis on a sample of Italian SMEs' networks. $62^{\circ}$ ICSB World Conference - Buenos Aires.

Bhati, S. S. (2015). Relation between trust theory and agency theory. In Natarajan, S., Ganesh, M. B., Nagarjuna, B. and Rajkumar, R. (Ed.). Commerce and Management - A Modern Perspective, Archers and Elevators Publishing House, India, pp. 57-65.

Babakus, E., Yavas, U. \& Haahti, A. (2006). Perceived Uncertainty, Networking and Export Performance: A Study of Nordic SMEs. European Business Review, 18(1), 4- 13.

Barney, J. B. \& Hansen, M. H. (1994). Trustworthiness as a source of competitive $\quad$ advantage. Strategic Management Journal, 15, 175-190.

Berry, A. (2002). The Role of the Small and Medium Enterprise Sector in Latin America and Similar Developing Economies. Seton Hall Journal of Diplomacy and International Relations, (1), $104-$ 119.

Blomstermo, A., Eriksson, K., Lindstrand, A. \& Sharma, D. D. (2004). The perceived usefulness of network experiential knowledge in the internationalizing firm. Journal of International Management, 10(3), 355-373.

Brouthers, K. D \& Bamossy, G. (2006). Post-formation processes in Eastern and Western European joint ventures. Journal of Management Studies, 43(2), 203-229.

Buatsi, S. N. (2002). Financing Non-Traditional Exports in Ghana. Journal of Business \& Industrial Marketing, 17(6), 501-522.

Burke, S., Sims, D., Lazzara, E., \& Salas, E. (2007). Trust in leadership: A multi-level review and integration. The Leadership Quarterly,18, 606-632.

Cannatelli, B. \& Antoldi, F. (2012). The role of network facilitator in fostering trust within strategic alliances: a longitudinal case study. Journal of Small Business and Entrepreneurship, 25(1), 19-33.

Creswell, J. W. (2009). Research design: Qualitative, quantitative, and mixed methods approaches (3rd ed.). Los Angles: Sage.

Creswell, J. W. \& Plano-Clark, V. L. (2007). Designing and Conducting Mixed Methods Research. Thousand Oaks, CA: Sage Publications.

Cavusgil, S. T., \& Noar, J. (1987). Firms and management characteristics as discriminators of export marketing activity. Journal of Business Research, 15(3), 221-235.

Chetty, S. \& Blankenburg, H. D. (2000). Internationalisation of Small to Medium-sized Manufacturing Firms: A Network Approach. International Business Review, 9(1), 77-

93.

Coviello, N. A \& Munroe, H. (1997). Network relationships and the internationalization process of small software firms. International Business Review, 6(4), 361-386.

Creed, W. E. D. \& Miles, R. E. (1996). Trust in organizations: A conceptual framework linking organizational forms, managerial philosophies, and the opportunity costs of controls. In Kramer, R. M. and Tyler, T. R. (Ed.). Trust in organizations: Frontiers of theory and research, Thousand Oaks, CA: Sage Publications.

Easterby-Smith, M., Thorpe, R. \& Lowe, A. (2004). Management Research: An Introduction (2nd ed.). London: Sage Publications.

Fink, M. \& Kessler, A. (2010). Cooperation, trust and performance-empirical results from three countries. Br J Manag, 21 (2), 469-483.

Fukuyama, F. (1995). Social capital and the global economy. Foreign Affairs, 74(5), 89-103.

Geyskens, I., Steenkamp, J. B. \& Kumar, N. (1998). Generalisations about trust in marketing channel relationships using meta-analysis. International Journal of Research in Marketing, 15(3), 223-248.

Ghauri, P., Lutz, C., \& Tesfom, G. (2003). Using networks to solve export-marketing problems of small and medium-sized firms from developing countries", European Journal of Marketing, 37(5/6), 728-752.

Ghana Export Promotion Authority. (2017). Report on analysis of 2017 non-traditional export statistics. Accra: Author.

Ghana Export Promotion Council. (2010). NTE Performance Report. Accra: Author.

Gronroos, C. (2000). Service Management and Marketing. Chichester: Wiley.

Hair, J. F., Black W.C., Babin B. J., Anderson R.E., \& Tatham R. L. (2006). Multivariate (6th Ed.). New Jersey: Pearson Prentice Hall.

data analysis

Hakansson, H., \& Johanson, J. (1993). Network as a Governance Structure. In Grabher, G. (Ed.). The SocioEconomics of Industrial Networks, London: Routledge.

Hakansson, H. \& Snehota, I. (1995). Developing Relationships in Business Networks. $\quad$ London: Routledge. 
Hewett, K. \& Bearden, W. O. (2001). Dependence, trust and relational behaviour on the part of foreign Journal of Marketing, 65, 51-66.

Hinson, R. (2005). Internet adoption among Ghana's SME non-traditional exporters: Expectations, realities and barriers to use. Africa Insight, 35(1), 20-27.

Hite, J. M. (2000). Patterns of multidimensionality of embedded network ties in emerging entrepreneurial firms. Paper presented at the Academy of Management, Toronto.

Ismail, M. D. (2011). Role of trust in SMEs export performance. International Conference on Management, Economics and Social Sciences, 499-503.

Ibeh, K. (2003). Towards a contingency framework of export entrepreneurship: Conceptualizations

and empirical evidence", Small Business Economics, 20(1), 49-68.

Johnsen, R. (1999). International market development through networks: The case of the Ayrshire knitwear sector. International Journal of Entrepreneurial Behaviour \& Research, 5(6), 297-312.

Kastner, A. (2005). Competiveness of Ghana's horticultural export sector. In Kuada, J. (Ed.). Internationalization and Enterprise Development in Ghana, Adonis \& Abbey, London, pp. 25-53.

Kyereboah-Coleman, A. \& Biekpe, N. (2006). Corporate governance and financing choices of firms: a panel data analysis", South African Journal of Economics, 74(4), 670-681.

Lau, E. \& Rowlinson, S. (2010). Trust relations in the construction industry. International Journal of Managing Projects in Business, 3(4), 693-704.

Laws, S., Harper, C. \& Marcus, R. (2003). Research for Development. London: Sage Publications.

Li, P. (2007). Towards an Interdisciplinary Conceptualization of Trust: A typological approach. Management and Organization Review, 3, 421-445.

Lorenzoni, G. \& Lipparini, A. (1999). The leverage of inter-firm relationships as a distinct organizational capability. Strategic Management Journal, 20(4), 317-338.

Lyon, F. (2000). Trust, networks and norms: The creation of social capital in agricultural economies in Ghana. World Development, 28(4), 663-682.

Massaro, M., Moro, A., Aschauer, E \& Fink, M. (2017). Trust, control and knowledge transfer in small business networks. Rev Manag Sci, Springer.

Macpherson, A. and Holt, R. (2007). Knowledge, learning and SME growth: A systematic review of the evidence. Research Policy, 36(2), 172-192.

Ma J. \& Orgun, M.A. (2006). Trust management and trust theory revision. IEEE Transactions on Systems, Man, and Cybernetics-Part A: Systems and Humans, 36(3).

Madhok, A. (1997). Cost, value and foreign market entry mode: The transaction and the firm. Strategic Management Journal, 18, 39-61.

Ministry of Trade and Industry. (2011). Trade Policy Paper. Accra: Author.

Misztal, B. (1996). Trust in Modern Societies. Cambridge, MA: Polity Press.

Moro A, Fink M, \& Kautonen, T. (2014). How do banks assess entrepreneurial competence? Public data vs. voluntary information disclosure", International Small Business Journal, 35(5), 525-544.

Morgan, R. M. \& Hunt, S. D. (1994). The commitment-trust theory of relationship marketing", Journal of Marketing, 58(3), 20-38.

Nicholson, C., Compeau, L. \& Sethi, R. (2001). The role of interpersonal liking in building trust in longterm channel relationships. Academy of Marketing Science Journal, 29 (1), 3-15.

Owusu-Frimpong, N., \& Mmieh, F. (2007). An Evaluation of the Perceptions and Marketing Practices of NonTraditional Exporters in Ghana. Thunderbird International Business Review, 49(1), 57-76.

Parkhe, A. (1998). Building trust in international alliances. Journal of World Business, 33(4), 417-437.

Putnam, R. D. (1993). Making democracy work. Civic traditions in modern Italy. Princeton, NJ: Princeton University.

Roloff, J. (2008). Learning from multi-stakeholder networks: issue-focussed stakeholder management. Journal of Business Ethics, 82(1), 233-250.

Ring, P. S. (1996). Fragile and resilient trust and their roles in economic exchange. Business and Society, 35(2), 148-175.

Ring, P. S. \& Van De Ven, A. H. (1992). Structuring cooperative relationships between organizations. Strategic Management Journal, 13(7), 483-498.

Rutashobya, L. \& Jaensson, J. (2004). Small firms Internationalization for Development in Tanzania: Exploring the network Phenomenon. International Journal of Social Economics, 31(1), 159-172.

Ruzzier, M., Hisrich, R. \& Antoncic, B. (2006). SME internationalization research: Past, present, and future. Journal of Small Business and Enterprise Development, 13(4), 476-497. 
Sako, M. (1998). Does trust improve business performance? In Lane, C. and Backman, R.

(Ed.). Trust within and between organizations: Conceptual issues and empirical application, Oxford University Press, Oxford, pp. 88-117.

Sako, M. (1992). Prices, Quality and Trust: Buyer Supplier Relationships in Britain and Japan. Cambridge: Cambridge University Press.

Saunders, M., Lewis, P. \& Thornhill, A. (2009). Research methods for business students (5th ed.). Edinburgh Gate, Harlow: Pearson-Prentice Hall.

Sharma, K., \& Morrissey, O. (2006). Trade, Growth and Inequality in the Era of Globalisation. London: Routledge.

Svensson, G. (2005). Mutual and interactive trust in business dyads: condition and process. European Business Review, 17(5), 411-427.

Tabachnick, B. G., Fidell, L. S. \& Osterlind, S. J. (2007). Using multivariate statistics (5th Ed.). Boston: Allyn and Bacon.

Tashakkori, A., \& Teddlie, C. (2003). Mixed Methods in Social and Behavioural Research. Thousand Oaks, CA: Sage.

Thomas, K. W., \& Tymon, W. G. (1982). Necessary properties of relevant research: lessons from recent criticisms of the organizational sciences. Academy of Management Review, 7, 345-352.

Tyler, K. \& Stanley, E. (2007). The role of trust in financial services business relationships. Journal of Service Marketing, 21(5), 334-344.

United Nations Industrial Development Organisation. (2007). Annual Report. Author.

United Nations Industrial Development Organisation. (2004). Annual Report. Author

Warrington, T. B., Abgrab, N. J., \& Caldwell, H. M. (2000). Building trust to develop competitive advantage in e-business relationships. Competitiveness Review, 10(2), 160-178.

Watson, M. (2005). Can There Be Just One Trust? A Cross-Disciplinary Identification Of Trust Definitions And Measurement. A submission to the Institute for Public Relations for the 2004 Ketchum Excellence in Public Relations Research Award [online] available from $<$ www.instituteforpr.com $>\left[11^{\text {th }}\right.$ May 2010]

Welter, F. (2012). All you need is trust? A critical review of the trust and entrepreneurship literature. International Small Business Journal, 30(4), 193-212.

Wignaraja, G. (2003). Competitiveness Analysis and Strategy. In Wignaraja G. (Ed.), Competitiveness Strategy in Developing Countries: A Manuel for Policy Analysis, $\quad$ London: Routledge.

Van de Ven, A. H. \& Ring, P. S. (2006). Relying on trust in cooperative inter- organizational relationships. In Bachman A. and Zaheer, A. (Ed.). Cheltenham: $\quad$ Edgar Elgar. 